Title: More than Murder: Ethics and Hunting in New Zealand

Author(s): Kass Gibson

Copyright, publisher and additional information: Manuscript has been published in a journal issue. Pre-print author manuscript version reprinted, by permission, from Sociology of Sport Journal, 2014, 31 (4): 455-474, https://doi.org/10.1123/ssj.2014-0106. @ Human Kinetics, Inc.

DOI: https://doi.org/10.1123/ssj.2014-0106

Reference: Gibson, K. (2014). More than murder: ethics and hunting in New Zealand, Sociology in Sport Journal, 31(4), 455-474, https://doi.org/10.1123/ssj.2014-0106 
Author pre-print version, there may be minor changes in the final version

Gibson, K. 'More than murder: Ethics and hunting in New Zealand.' Sociology of

Sport Journal, (31)4: 455-474.

\title{
More Than Murder: Ethics and Hunting in New Zealand
}

\author{
Kass Gibson \\ University of St. Mark \& St. John
}

In this article I examine the practice of hunting in New Zealand with particular reference to the ways in which hunters make sense of hunting, the embodied experience of hunting, and the moral status of animals. Drawing on ethnographic and interview data I reflect on how the practice and understanding of hunting is guided by a form of relational ethics. As such, the social and historical development of hunting in New Zealand and meaningful connections made with the environment and animals developed through the practice of hunting work to guide hunter's ethical perspectives rather than any universalized philosophical principles or rules. I argue that by hunting, hunters recognize and consciously engage with multiple standpoints and interests in the backcountry environment in a manner that presents particular challenges to critical studies of human-animal interactions that are frequently unable to look past hunting as killing. As such, this article works to explicate the "experiential and cultural complexities" (Marvin, 2011 p.123) of hunting with particular emphasis on the development of an ethical perspective that guides hunters in New Zealand without seeking to judge, or defend, hunting and hunters.

Hunting is subject of much emotive debate, both in academic and lay circles, and as such has not escaped the attention of sociologists of sport. That being said, sociologists of sport have primarily concentrated on fox hunting (e.g., Elias \& Dunning, 1986; Stokvis, 1992) which holds obvious draw given the highly politicized and classed nature of fox hunting. More broadly, scholars have critically reviewed the 'sportization' of hunting and whether the killing of animals be considered or condoned as sport (Bronner, 2008; Laufer, 2012; Marvin, 2010; Ortega, 1972; Swan, 1995). Naturally, such conversations address the defensibil- ity of killing animals in the absence of any critical need for sustenance (Bulliet, 2005; Garner, 2005; Herzog, 2010; Kheel, 2008; Scrutton, 2000). This article does not work to examine hunting as a sport instead focusing on how the practice of hunting is guided by a particular ethical perspective developed through the lived experience of hunting in relation to the unique social, historical, and ecological development of New Zealand.

\section{Methodological Approach}

This study draws on over 100 hours spent hunting with deer, chamois, and tahr hunters in New Zealand. Entrée was obtained through personal networks and those I hunted with invited me to join other hunts and introduced me to other hunters. In this regard it is worth noting that hunters in New Zealand are generally willing to take anyone hunting and indeed often voiced the feeling of responsibility in ensuring knowledge, skills, and values being transmitted to others who wished to hunt (cf. Hunter, 2008). Thus, entrée was not a particularly difficult process. 
In the field my role would be negotiated, formally and informally, in rela- tion to both the length of time I had known the hunter and the type of hunting being conducted. In Gold's (1958) classic terms, my role in hunting expeditions varied between accompanying hunters as a complete observer to actively hunting alongside them as participant as observer. Given the presence of firearms my role would generally move from observer to participant over time as the hunter and I became more familiar with each other and they became more comfortable with my competencies around rifles to the point where I would shoot animals. Involvement also reflected what and how we were hunting. For example, when hunting chamois and/or tahr in alpine environments much time is spent is 'glassing' (identifying animals from lower down the mountain or across valleys through binoculars), a process which I could take an active role in immediately. Across all hunts I would consistently be involved in 'carrying out' animal carcasses either as part of a team effort when an animal (usually a large red deer) might be too heavy for one person to carry out. Carrying out also functions as part of an introduction to the realities of hunting. Oftentimes, those new to hunting are tasked with carrying out animals as a way to contribute to the hunt given your "guide" has located and (usually) shot the animal. Feeling the weight of animals on my back as I scrambled to carry them out across difficult areas of backcountry was a deeply challenging physiological task. As such, the effort and struggle pointed me toward, like Marvin (2005, p.16), an understanding of hunting as a:

fully embodied multi-sensory and multi-sensual practice that depends on an immersion into a multi-sensory and multi-sensual world. Hunting is more than killing - it concerns a way of being in a particular space and incorporates particular forms of engagements with animals. It involves the hunter contest- ing his or her abilities with and through animals rather than the enjoyment of their domination. A good deal of the pleasure of hunting is the skill of creating the conditions in which the animal will be encountered whether the hunter is finally able to take a shot or not.

Particular attention during hunts was devoted to the ways in which the lived experience of hunting was dialogical with the social and cultural practices of hunting. In addition to the time spent 'in the bush' and 'on the hill' with hunt- ers, numerous hours were spent driving to and from hunting locations (usually known as 'blocks') as well as socializing with hunters in pubs and at their homes variously butchering, cooking, and eating the harvested animals. As part of these ethnographic conversations we would frequently discuss not only the practical and logistical aspects of hunting but also the ways in which hunters made social sense of hunting, the embodied experience of hunting, and the moral status of animals. Field notes from hunts as well as our conversations were taken overtly and with direct input from hunters. In reviewing these notes a relatively consistent ethical perspective and imperative related to hunting, dialogical with specific geographical, sociological, and historical developments in New Zealand, was evident. Further analysis of data revealed a complex, and at times contradictory, ethical reason- ing process for hunters. Given the political advocacy evident in critical studies of human-animal this research works to 
articulate the ethical perspectives that orientate the practice of hunting rather than seeking to judge, or defend, hunting and hunters (see: Swan, 1995). Participating directly in hunting, then, realized the classic advantage of participant observation studies in that the researcher is able to see and experience firsthand the practices of hunters rather than relying on accounts being provided at a later date in interviews. Indeed, this is particularly important in studying what might be considered a 'tolerably deviant practice' (Atkinson \& Young, 2008) as participants might provide idealized narratives to appease perceived persecutory biases held by outsiders generally and researchers specifically (Adler \& Adler, 1985; 2000).

Twenty-one hunters based in Canterbury, New Zealand were interviewed in addition to the participant observation process. Interview participants were obtained through both snowball techniques based on those I hunted with as part of participant observation as well as approaching three hunting organizations directly. Interview participants were males ranging in ages from 19 to 56 with between two to more than thirty years hunting experience. Although no formal typology (cf. Daigle, Hrubes, \& Ajzen, 2002; Miller \& Vaske, 2003; Woods \& Kerr, 2010 ) or theoretical sampling procedures were deployed, hunters who hunted primarily for developing a connection with nature and the harvesting of animals for consumption as food rather than trophies were purposefully targeted. Such a decision was made given that there is a significant divergence in hunting practices between trophy and other forms of hunting (Kellert, 1978; Radder, 2005) which would warrant further explicit attention. No specific information regarding socioeconomic status or occupation was collected, participants tended to be either skilled tradesmen (e.g., builders and electricians) or from professional backgrounds (e.g., engineers and teachers). However, it is worth acknowledging that for all participants, hunting was a chosen recreational pursuit and not a means of sustenance. In short, this was a purposive sample but should not be read as representative of all deer, chamois and tahr hunters in New Zealand. Pseudonyms have been used with all reported data.

Interviews were semi structured based around a list of approximately twenty questions developed in relation to the initial analysis of participant observation data. Questions were designed to gain insight into participant's experiences, values, and practices related to hunting while explicitly and critically examining my conceptual reading of participant observation data. Following these methodological practices the data and analysis presented in this paper are made with the recognition that the arguments forwarded here are inherently nongeneralizable. That caveat notwithstanding, the perspectives forwarded resonated with, and were developed alongside, hunters and as such I am confident in the accuracy of the theoretical interpretation and my contentions made in relation to hunting in New Zealand.

Given that the focus of this paper revolves around ethical perspectives of hunters it would be remiss not to mention ethical issues faced during this research. Despite Lovelock's (2008, p.3) correct observation that hunting, for critical sociocultural researchers, "falls between the uncomfortable (guns, firearms) and the unforgiveable (killing Bambi)" from an institutional review perspective 
ethical issues in studying hunting are relatively uncomplicated. As will be outlined below, the legal status of hunting is rather straightforward in New Zealand and all those I hunted with adhered to legal requirements as related to firearms license and land access. As such, hunters can, and should, be considered, approached, and addressed as any other (sub)cultural group routinely studied in sport and physical culture. Less formally, being directly involved in the practice of killing and butchering animals provided both moments of discomfort and cause for reflection on my ethical imperatives and values. At the core of my discomfort is not the death of the animal per se but the manner and purpose in which that death has been brought about (cf. Tyrrell, 2010). Articulating my reflections as well as engaging them directly through engaging in hunting provided methodological leverage in generating frank discussions about ethical perspectives in and on hunting. Indeed, as is demonstrated below, my feelings of discomfort were articulated and shared by other hunters and at no time did I witness hunters attempting to inflict suffering (besides a quick death) on any animal. Somewhat paradoxically, then, it has been by looking past death that a greater understanding of killing is achieved. For, as Marvin (2011 p.123) notes

from outside hunting, especially if one has a critical view, it is easy, perhaps inevitable, to focus on the fact that animals are killed. However, as with bull- fighting such a focus is too narrow for understanding the nature of hunting and its experiential and cultural complexities; complexities that can only be explained by hunters themselves.

Finally, as will be mentioned throughout this article, generating sound understandings of human-animal relations, particularly in sport, will often require researchers to question and reflect upon their a priori assumptions and political and ethical convictions rather than simply pointing to the existence of practices such as hunting as evidence for their position.

\section{The Development of Hunting in New Zealand}

Critiques of violence toward animals for consumption, in the broadest possible sense, correctly argue that certain species are defined as valuable for certain con- sumptive practices as a result of social values, cultural practices, geographical proximity, and historical precedent rather than any inherent qualities of the animals themselves (Herzog, 2010; Weitzenfeld \& Joy, 2014). There is no escaping this point. Moreover, the narratives of the hunters I spoke to and hunted with are only understandable in relation to the nuances of the environment in which they hunt. Therefore, a brief review of the social, political, and historical development of hunting in New Zealand is provided below. The most important contextual factor to appreciate, especially in relation to hunting, is that all land-based mammals in New Zealand (humans included) are relative newcomers; the only 'nonmarine' mammals endemic to the archipelago are two species of bat. The target species for hunters in this research were released in New Zealand specifically for the purpose of hunting and as part of acclimatization societies 'enrichment' of landscapes and environments in the late-nineteenth and early-twentieth centuries more broadly (Anderson, 1992). The Nelson Acclima- tisation Society introduced the first red deer in New Zealand in 1854, while other societies procured tahr and chamois released in 
what is now the Aaorangi National Park at the turn of the twentieth century. In terms of animal numbers liberations were overwhelmingly successful. Yerex (2001) estimates that by 1919 approximately 300,000 red deer were in New Zealand and numbers were increasing by $25 \%$ each year. Similar growth in animal numbers were evident among other game species courtesy of the benign New Zealand climate and limited predators and competitors.

Animal procurement and liberation reflected a complex amalgam of vested interests, particularly of those in positions of relative power and classed, gendered, and racialized notions of hunting in England (Curry, 2004). The classed notions of hunting are evident in New Zealand émigrés shunning hunting the previously released and by then abundant goats, pigs, sheep, and cattle, instead working to replicate the hunting practices of their aristocratic families at home. Moreover, deer for release in New Zealand were sourced from renowned game parks in Eng- land and Scotland including Warnham Court, Stoke Park, and the exclusive Royal herd at Windsor Great Park (Banwell, 2011). Game hunting was a valued practice almost exclusively for males so that they might to develop proficiency with fire- arms to contribute to national defense. Further, hunting resonated with discourses and exhibitions of masculine independence through stoicism and resourcefulness to go without modern conveniences by 'living off the land' (McLeod, 2007). The historical importance of division of labor and gender-based roles in the development of hunting has received much attention (Adams \& Donovan, 1995; Stange, 2003) much of which is critical of hunting as instantiating and perpetuating masculine violence that reinforces and reproduces gender-based discriminatory behaviors (Kalof, Fitzgerald \& Baralt, 2004; Luke, 1995). Certainly, hunting in New Zealand resonates with aspects of the development of a particularly desirable masculinity particularly in relation to the New Zealand cultural icon of the Good Keen Man (Crump, 1960; 1992).

However, the relatively recent historical emergence of big game hunting in New Zealand meant that hunting in New Zealand developed pri- marily in relation to class- not gender-based antagonisms.

In New Zealand hunting is predominantly conducted on public land. Therefore, while the motivations for game liberation were classed to the extent that certain powerful and privileged groups wished to replicate the hunting practices they valued as ennobling activities, the act of hunting game worked to subvert many class ideologies. Of particular importance is the absence of the punitive English game laws, which restricted access to both land (via game park systems) and animals (via private ownership of animals) to make hunting, particularly deer, the preserve of the aristocracy. New Zealand hunting has been largely devoid of such class antagonisms; something celebrated by all hunters I met. That being said, hunting permits in New Zealand were subject to strict controls. A nationwide ban on deer-stalking was in place until 1870 after which a strictly enforced one month hunting season was established and hunting restricted to members of acclimatization societies. The legal protection of game animals also cut across relationships between Maori and Pakeha (New Zealand Europeans) and game introduction impacted on the practices of Maori through the denial of access to certain areas of land as well as placing hunting restrictions on native 
fowl game, particularly kereru-a large arboreal pigeon endemic to New Zealand-to the extent that hunting kereru was outlawed in the 1920s (Feldman, 2001).

By the 1930s discourses regarding game animals began to shift dramatically from enrichment of an empty landscape that concomitantly provided opportunities for hunting to a discourse concerned primarily with conservation (Curry, 2004; Fig- gins \& Holland, 2012; Parkes \& Murphy, 2003). The aforementioned rapid growth in animal numbers resulted in widespread damage to native bush. The development of increasingly efficient transportation technologies, the establishment of New Zealand's national parks, and the formulation of outdoor clubs meant that Pakeha were entering into the wilderness more frequently. Therefore, damage which might have gone unnoticed except to rural workers, hunters, and other animals in the bush became a focus of political discourse and moral concern among Pakeha manifest in an increasing sensitivity toward protecting native bush (Curry, 2004; Lovelock, 2008). Introduced species became the prime target for conservation efforts thus all legal and bureaucratic restrictions on hunting them were lifted. To this day hunting, which functioned as a symbol of nobility in the 'mother country' (Banwell, 2011) and/or reflected the interest of capital via private owner- ship in North America or restrictive quota based systems (Bronner, 2008; Dizard, 1999), is able to be conducted freely on all public lands with the exception of Waipiti (Banwell, 2001) and fowl (McLeod, 2007). In short, the New Zealand hunting context is unique in that all game species are introduced and the only legal requirements are that the hunter holds a firearms license.

\section{Hunting and/as Conservation}

The difficult relationship between conservation efforts and hunting is well documented (Kheel, 2008; Laufer, 2012; Leopold, 1966, 1991a; Rolston, 1988; Varner, 1998). Hunting as a conservation practice in New Zealand differs greatly from other regions in that state sanctioned conservation efforts are designed to protect the environment from game and not for game. Said differently, introduced game is part of the environmental problem rather than the target of conservation efforts. In addition to encouraging recreational hunting as a conservation strategy the state somewhat inverted the aforementioned relationship between hunting and the military by establishing a cadre of professional hunters known as deer cullers. The forebodingly named 1930 'Deer Menace' conference established professional hunting as a viable public works project in response to the rising unemployment levels and supplied cullers with left over ammunition and rifle stocks from the Great War (Willems, 2009). Despite culling over a million animals between 1930 and 1956 (see: Harris, 2002; Hunter, 2008; Yerex 2001 for more specific figures) culling was largely ineffectual as a conservation strategy. It would be the development of commercial interests, particularly in venison, that would have the greatest impact on game animal numbers in New Zealand.

From about the 1950s the commercial value of deer would rise steadily on the back of strong markets for velvet and hides. In the 1960s New Zealand underwent what is colloquially known as the 'venison boom' courtesy of a 
dramatic rise in wild venison prices combined with the establishment of offshore markets. Initially commercial hunters employed the same ground based methods, familiar to any recreational hunter and government deer cullers, although often with the support of fixed wing aircraft for dropping in supplies and retrieving carcasses (Caughley, 1983; Parkes, Nugent \& Warburton, 1996). Helicopters would replace fixed-wing aircraft and in doing so truly revolutionized hunting in New Zealand. At first helicopters functioned as more efficient versions of fixed-wing aircraft. However, improving technology, especially in relation to the altitude at which helicopters could fly, led to helicopters being used in the direct harvesting of animals. Commercial hunters and pilots combined to form 'gunship' teams where hunters would shoot animals directly from the aircraft.

As deer numbers necessarily declined from intense commercial hunting pressure, experiments in the feasibility of deer farming began to be conducted. Thus in the 1970s commercial hunting efforts were redeployed toward live animal recovery. Gunshipping gave way to 'bulldogging' where the helicopter crewmember would leap from the airborne machine onto an animal to wrestle it to the ground and capture it live for agricultural domestication. Following the establishment of deer farming, game estates began to be developed. Game estates, primarily hunted by American and European trophy hunters (Yerex, 2001), have been subject to much criticism primarily from recreational hunters who are concerned that commercial interests will erode their ability to access land and also question the purpose and merits of canned hunts (Laufer, 2012; Lovelock, 2008). Figgins (2008) notes that no reliable figures regarding the total game estate industry exists in New Zealand, however, available figures suggests that consumptive wildlife tourism (Lockwood, 2008) both in game estates and guided hunts on public land, are increasing in popularity if not profitability. The commercial harvesting of game animals (both live and dead) demonstrated not only the positive impact, from the perspective of native flora and fauna, reducing game animals would have, but also the impossibility of total eradication (Challies, 1985; Holloway, 1991). Thus, as commercial operations wound down, conservation strategies became more particular by focusing on areas where animal numbers were particularly high and/or areas of particular interest or fragility. The 1977 Wild Animal Control Act (WACA) reclassified animals from pests to 'wild animals' and conservation strategies were oriented toward reduction of animal populations that were sustainable for the environment and not as a result of hunter advocacy or necessarily in the interest of hunters. The social, political, economic, and 'sporting' complexity of the changing status of hunting and the position of animals in New Zealand as variously and concomitantly game, pests, or commercial resource forms the complicated backdrop against which this study was conducted. What is important to comprehend here is that since the 1930s game in New Zealand have, for hunters at least, a genuine social and cultural value that is secondary to native flora and fauna. The practice and purpose of hunting in New Zealand has developed in tandem with shifting social, economic, and legislative changes. From such a perspective, any positioning of hunting (especially in New Zealand) as a simple case which posits a practice based on one way exhibitions of power and dominance reminiscent of masculine/ feminine, nature/culture, hunter/hunted dichotomous relationships 
is empirically inaccurate. That is not to deny that historical and contemporary hunting practices in New Zealand developed in relation to particular masculine subjectivities or ignore the very real acts of violence that take place, but rather serves to highlight the multiple subjectivities, agents, and environments in which hunting takes place.

\section{The Relational Perspective}

Relational ethics is an umbrella term for the development of ethical sensitivities that work to negotiate between the effects following actions and intentions for acting. As a basic starting point, then, we can take relational ethics to work toward a synthesis of the longstanding philosophical debate between consequentialist notions of ethics and deontological perspectives. Hunters variously emphasized that given certain contexts neither the consequences nor the intention of hunting could be universally relied on in understanding what they would class as an ethical hunting act. For example, a cause of much consternation among all hunters is a 'gut shot' animal, whereby the shot is insufficient to kill the animal. The gut shot animal then evades the hunter usually dying some time later after what is generally accepted as a painful (and wasteful) death. Thus, while all hunters emphasized minimizing animal suffering through a "clean kill" as an important aspect of their hunting practice, regardless of their intent not to cause suffering, hunters consider a gut shot as a violation of ethical hunting practice. However, a quick and painless death for the animal alone would not constitute an ethical hunt either. While field dressing (butchering an animal in preparation for carrying out) a tahr Trev told me "the reason you are hunting is important too, if you're just out to kill things then there is something wrong with you. People hunt for different reasons, trophies or meat or whatever, but not for the purpose of killing. Hunting involves killing, but killing is not hunting." The responsibility to minimize suffering comes from developing a relationship with animals throughout the entire process of hunting as evidenced by Jason, who has been hunting for two years and who explained the complicated and at times contradictory practices of killing animals as follows:

I don't get any pleasure out of killing an animal. There is a sense of achievement, sure, but that comes from the whole hunt: getting your gear ready, heading into the bush, sorting out your bivvy or getting the fire in the hut going, seeing sign, finding the animal, getting into position, and then taking the shot. Then you've got to get the animal out. I like to take all that I can so that can be a real challenge, then you've got to butcher it, hang it, and then prepare a meal.

While hunters differed as to whether they 'felt bad' after killing an animal I never witnessed or heard any hunter taking pleasure in the act of killing itself. As such, in speaking directly to hunters about what they see as ethically defensible in hunting it quickly became apparent that there were no acceptable principles that could hold in any hunting context for the hunters themselves. Thus, I began to explore the basis of ethical frameworks that did not rely on a priori ethical principles or, in line with critical animal studies and animal standpoint theory perspectives, notions of rights (Beauchamp et al., 2008; Best, 2013; Davis, 2014; Tester, 1992). Importantly, hunters stress hunting as a practice conducted with 
explicit and valued engagement with nontarget species. Further, the embodied, multisensory experi- ence of the landscape and physical geographies of the hunt is a central component of understanding what it is to hunt. As such, hunting in the New Zealand context emphasizes the importance of ethical practices based on multiple relationships between hunters, the environment, and other animals therein not just hunter and prey.

In the remainder of this paper I work to demonstrate how a relational perspective can be used to understand hunting practices and in doing so advance the need to understand ethical reasoning and practice as contextually-based. This is not to deny the death of animals or to justify hunting; instead, it is to signify the importance of understanding the range of social acts in hunting that form the ethical perspectives that shape hunting as a practice.

\section{Building Relationships}

Franklin (2008, p.38) notes that hunters as well as anglers articulate a different engaging with animals as attributable, in part, to a desire to escape "the humancentred world". Hunting, then, provides "an opportunity to live less by our intellect and more by our senses, and an opportunity to relate intimately to other species as opposed to our own" (Franklin, 2008 p.38). Similarly, Dizard (1999) notes that ani- mals in the wild are generally considered to be 'closer to nature' than domesticated animals, be they companion animals or livestock, and as such are generally held with particular reverence. From such a position we can see that the 'naturalness' of wild animals imbues them with a particular moral status, which forms the basis of imperatives for protection from direct and indirect actions of humans. Indeed, this much is evident in the WACA outlined above. Moreover, meeting animals in their own environment is also generative of a particular kind of experience as wild animals generally dictate the extent of interaction with the humans (Atkinson \& Gibson, 2013). Obviously, in the animal's 'natural' environment, the hunter needs to maximize the opportunity for seeing an animal for a sufficient amount of time and within sufficient proximity to make a successful shot. Importantly, the hunters I spoke with cannot dictate the terms upon which this interaction takes place. The comments of experienced tahr and chamois hunter Avi, longtime deer hunter Hugh, and Steve, who has been hunting for five years, reflect this:

You can't just wander up the mountain with a firearm and expect to shoot a tahr. You need to have a good look at the topography, know what the weather is going to do, and most of all know what the animals are up to. In the summer tahr have a thinner coat and are lower [down the mountain] in winter they have their winter coat, which they've developed to withstand inhospitable conditions in the Himalayas, which New Zealand just doesn't have. So, in winter you'll need to get right up to the tops [of the mountains]. If you're planning on bivving near the tops in the middle of summer when it's much nicer for us to be up there you're not going to see many animals. You might find them later in the day when they head to the peaks in the wind to cool themselves, but then you need to be on their leeside [down wind] so you have to figure out how to get 
around the mountain and you've got to do all this as quietly as you can on precipitous scree slopes (Avi).

A key difference between new and experienced hunters in the recognition that there is no need to take a shot the second you see an animal. The more experienced hunters realise what goes into making a shot and it requires quite a bit more than just a good aim. You need to determine if you are in a good position and if not work out if you are able to yourself into a better position [for taking a shot]. If that's not possible then you just have to know that you'll see another animal again at some point. When I've taken out new hunters I've had to stop them taking shots because I know we are not in a good spot, it might be right at the limit of their range, say, and explain to them that this will not be our only chance. That is the key difference between experienced and inexperienced hunters, knowledge of the animals to not just find them but to find them in a good range (Hugh).

I hunted a lot with experienced guys when I first started and it was really helpful. My first few solo hunts I seldom saw an animal and when I did we either saw each other at the same time, or I simply saw their tail as they raced away through the bush. What I learnt from those guys had very little to do with the technical side of hunting [firearms and ballistics] and much, much more to do with learning about the animals themselves (Steve).

To shoot an animal hunters necessarily develop an intricate knowledge of the animals and their behavior. In other words, they start to develop a relationship with the animal. From a relational perspective, then, the hunters I spoke with worked toward a goal of generating a more intimate understanding of the target species more so than they did their shooting abilities. For example, few hunters practiced shooting beyond developing the ballistic characteristics of their firearms and ammunition to a desired functionality. That is not to say that hunters were ignorant or uninterested in such considerations. Dave, who has been hunting for 15 years and described himself as "a bit of a gun-nut", would speak at length about ballistic issues during our hunts. Mechanical engineer Steve recounted the applicability of his vocation to setting up his firearms. Both of these hunters, then, were particularly interested in 'the technical side' of hunting. However, far more time, effort, and expense is devoted to books and resources on animal behavior, GPS devices, topographical maps, and technologies for reading the weather than improving the efficiency and accuracy of their shooting. The central focus of hunting for those I encountered in fieldwork is making an extensive time commitment developing their knowledge of their target species primarily through the act of hunting.

To be clear, increasing knowledge of the animals is oriented toward increasing the likelihood of being able to kill them. However, to reduce this just to the act of killing is to grossly simplify the complex relationship hunters share with animals. After we spooked a large red hind before being able to take a shot, Clyde, who has been hunting deer, chamois, and tahr for the past eight years, told me 
What you'll notice about a good hunter, and I'm not saying I'm one, is that they are far more connected with nature than other people. You can see it in the way they move through the bush, it's far quicker and a lot quieter than guys like you and me. They pick up windshifts and thermoclines almost instinctively and pretty much feel their way up the hills, in the tight and thick stuff [bush]. They don't think on their feet, they think with their feet, if that makes sense. Basically, a good hunter has to be as close to an animal in behaviour as they can.

Further, after three days hunting a block with Ben high in the Southern Alps that he has hunted for over fifteen years, we reflected on the animals we hunted:

Tahr are perhaps the most incredible animal you'll come across. They sprint up cliffs, literally vertical cliffs that we'd be getting out ropes and climbing gear to get up. I have such huge respect for those animals and it really is a paradox that I-try to-kill them, I know, but there's so much more to it than the shot you take. Anyone who thinks that being a hunter is just about killing has never been near a rifle let alone an animal.

In building relationships with the animals hunters both recognize and confront not only the subjective positions of the animals but also the multiple roles they, as hunters, occupy according to ethical, social, and political imperatives. In this study it is necessary to engage with the concept of hunted animals as food. In her path breaking analysis of the politics of meat, Adams (1999) argues that animals as food represent an 'absent referent' where the absence is the death of the animal. Adams (1999, p.13 emphasis in the original) explains,

The "absent referent" is that which separates the meat eater from the animal and the animal from the end product. The function of the absent referent is to keep our 'meat' separated from any idea that she or he was once an animal, to keep the 'moo' or 'cluck' or 'baa' away from the meat, to keep something from being seen as having been someone. Once the existence of meat is disconnected from the existence of an animal who was killed to become that "meat," meat becomes unanchored by its original referent (the animal).

However, Adams (1999) position, broadly championed in critical animal studies literature, bears little resemblance to the comments of thirty-year-old deerhunter, Sam:

It is a real pleasure preparing meals for people when you've shot the animal yourself. People really appreciate it and more than that when I'm eating the meat I'll often think about which animal it was. I don't mean whether it was a red [deer] or whatever, but the whole hunt. Where it was, how long it took to get, carrying it out, the whole trip. In my experience people quite like hearing those stories and it actually makes for a more intimate connection with your food as I really think about what it is I'm eating and I know exactly where it has come from. 
Similarly, Phil, who has hunted in New Zealand for over forty years and took me on my very first deer hunt, told me over dinner one night:

I truly believe that these animals [we shoot] have a good quality of life. How could they not? They are roaming around the bush and hills completely free then - bang - they get shot. They are not herded into stock trucks, they don't fret away in holding pens waiting to be "processed". I know exactly where my meat has come from in every possible way from the geography, to the individual animal, right down to the cut of meat.

Clearly, for hunters there is no absent referent in their meals. Moreover, seldom are the animals understood as an abstract entity. Given that game hunting in New Zealand rarely results in more than one animal and often results in no animals being harvested, hunters frequently ascribe individual traits and attributes to the animals evident in both the yarns told between hunters and in the abundant subcultural hunting literature. Such cognizance is developed through gaining an intimate knowledge through the life and death of animals (Stange, 1998). Therefore hunters build a relationship that generates a particularly complex moral status for animals generally as well as the specific animal harvested. For example, one relatively inexperienced hunter told me "the day I don't feel bad after killing an animal is the day I'll stop hunting".

As mentioned previously, the emotional response to killing an animal varies from sadness and unpleasantness to indifference, although all recognized and articulated the importance of respecting the animal in their death. The complexity of this relationship and the potential for an ethical foundation developed not despite, but because of killing that animal becomes clearer when a broader view of the practice of hunting and the relationships hunters build is taken into account.

Who and What is in the Relationship?

Multiple studies of hunter motivations have identified being in the 'great outdoors' as a primary motivation for hunting (cf. Woods \& Kerr, 2010). While resting after a long and arduous tramp into a DoC hut on the first night of a tahr hunt George and I discussed how:

being in the hills really makes you appreciate them on their own terms. That sounds a bit funny, but it does put your life into perspective in some ways, the artificiality of the environments in which we go about our daily lives. The bush reminds you about being alive, the feel of the sun in your face, the burn in your legs and lungs as you slog your way up the hill is just so different than hitting the gym or running around the block. I know I'll sound like a hippy, but it's about making a connection back with the land (George, tahr hunter).

Similarly, Rob told me as he butchered a tahr on the hill: 
Hunting takes you to places that other people simply have no reason to go to. The peaks we hunt are off the tramping tracks so trampers don't bother and they aren't summits on the radars of mountain climbers either. When you're out here, you glass then follow them. The animal dictates where you go and they take you into some of the most stunning scenery in the world.

When I put it to hunters that they could still go to these places and not take their guns the responses of deer-hunters Gary and Tom are typical responses:

I often do [not take my gun]. Or, I often find myself not taking a shot even though I can. Recently, I've been taking the camera as much as the gun and that's good fun too. Sometimes it's quite a bit more difficult to get a good shot with the camera than it is with the rifle (Gary).

Hunting is just one of the things I do outdoors. I often go tramping as well and have recently done a bit of mountaineering too. Hunting just makes you see things a bit differently. You're not sticking to a track or trying to get up a mountain for the sake of getting up the mountain. It facilitates a different experience (Tom).

The different experience of the land hunting facilitates advances the biomimicry and communion practices of fell runners (Atkinson, 2010) in that hunters actively identified making a connection with the land. The land, then, is an important party in the relationship and the subject of moral concern. The experience of the land is shaped by the animals primarily through the aforementioned ways in which they, as human actors, cannot predetermine the nature of the routes taken through the hills and alpine environments. As such, the experience of hunting is articulated through embodied experiences moving through nature facilitated by the animals. Contra to much of the relational ethics literature, however, these relationships have an inescapable violence.

Violence toward animals, in all its myriad forms, has predominantly been understood as a gendered and gendering act (Adams \& Donovan, 1995; Kalof, Fitzgerald \& Baralt, 2004; Kheel, 2008; Luke, 1995). The relationships hunters build with the animals they hunt, the environment in which they hunt, and the other animals they come across in their hunting are, from a relational ethics perspective, not built on abstract philosophical a priori but rather through consistent and considerate engagement with the aforementioned groups. Moreover, killing animals when hunting is not exclusively an act of domination (Leopold, 1991b) but also a component of working within a complex, interconnected, and fragile ecosystem. As noted biologist and ecologist Daniel Simberloff $(2003 ; 2005)$ has demonstrated, the introduction, purposeful or otherwise, of animals (and plants) beyond regions in which they established themselves without human intervention frequently results in devastating consequence for endemic species, which plays akey part in hunting for hunters in New Zealand (see also Figgins \& Holland, 2012). Baz, who has hunted deer for more than thirty years, told me: 
in areas where there are more deer there are less birds; it's that simple. I mean, that's the whole basis of DoC's work. Now, obviously other animals, especially possums, are a far bigger threat to native birds because they kill birds and not just destroy their habitat. Hunting, no matter what way you look at it, has a positive impact for the animals we don't hunt. We're not taking food away from other animals when we hunt we're putting more in the mouths of those we don't.

Perhaps the most advanced articulation of this perspective is Leopold's (1991a, $1991 b)$ land ethic. In viewing themselves as part of a broader ecosystem and not in hunter-hunted binaries, hunters (in Leopold's terms) act as 'citizens of the land' and not conquerors. From such a perspective hunters articulated a moral foundation for which hunting contributes to based on a holistic view of the ecosystem rather than individual animals. Thus, while Leopold does not speak in the language of relational ethics per se the land ethic demonstrates many affinities with the relational perspective. The inherent violence of the practice of hunting, despite an avowed desire for protection of the land and respect for all the animals in the backcountry, reveals a central divide between the experience of hunting and the perspectives of animal standpoint theorists and critical animal studies (Best, 2013; Davis, 2014; Kheel, 2008; Weitzenfeld \& Joy, 2014) as the problematic between understanding animals in abstract categories (i.e., as species that form part of ecosystems) and understanding animals as individuals in their own right. In forceful, compelling, passionate and theoretically insightful research, animal standpoint theorists and critical animal studies research has argued that humanism and speciesism are mor- ally bankrupt and untenable. Oppression is oppression and violence is violence whether it is conducted against humans or animals. Certainly, the perspective of critical animal studies is a highly compelling one in the consumption of animals for research purposes, industrialized agriculture, or indeed sports where animals are taken from their natural environments and placed in rings, pits, and tracks. The power of such analyses is in the challenge they present to the relationships between humans and animals as predefined by humans. As mentioned above, such theorizing does not reflect the practices of hunters. Therefore, contra other forms of recreational activities in which humans and animals interact, hunters do so in a manner that is keenly aware of the need to understand animals and the environment from multiple perspectives and not a dyadic hunter-prey dynamic. Similarly, relational ethics analyses are primarily developed in healthcare settings with predefined, often dyadic, relationships (Held, 2006; Slote, 2007). Hunters recognize multiple (animal) standpoints and, importantly, where these standpoints are contradictory or even diametrically opposed. Chamois, deer, and tahr hunter Steve, who spent time as a conservation worker several years ago, articulated the difficulties of balancing competing interests in the backcountry as follows:

You can't have it both ways here. If you leave all the animals alone then the animals we hunt are going to end up in the ascendancy. You can't provide an environment that works for the birds and the native [bush] that also is home for deer, or tahr or whatever. It's a paradox that many people who view themselves as environmentalists, especially if they are 
not familiar with New Zealand, can't get their heads around. For the birds and the native to survive you have to keep the numbers of introduced species down, which means you have to kill them. Recreational hunting can't be the only way that you achieve that but it is one way that can contribute and can do so in a relatively specific way.

Clearly, conservation is an important component of hunting practice. However, it would be disingenuous to suggest that conservation is the primary reason, or even justification, for hunting. Instead, this points toward the untenability of positions that hold to political values of veganism (Kheel, 2008) and animal liberation (Best, 2013; Davis, 2014) for all animals. In this we see the single biggest sticking point for debates about the sociology and ethics of hunting in that those from such positions tend to base their analyses on the perspective and welfare of individual animals. Thus hunting is morally indefensible because individuals are killed. Further, the act of killing is an affront to the liberty of individual animals and degrades and demeans humanity. Therefore, while those like Peterson (2013, p.151) argue that 'the dependence of nonhuman animals on overall ecological health can expand concern for individual animal ethics into a comprehensive environmental ethic' there is little provision for not only how this might be achieved or how a comprehensive environmental ethic can address conflicting interests between animals, especially introduced versus endemic interests. Moreover, how are we to take the perspective of an animal when, in the case of this research, hunters engage with multiple animals:

Let's not sugar coat this, if you want to talk about hunting and ethics you can't escape the fact that we [hunters] kill things. The things we kill also kill things. I'm not talking about some kind of survival-of-the-fittest, killor-be-killed, law of the jungle, thing here. The animals I hunt all have been introduced and all cause serious damage to the environment, which has a pretty big impact on the other animals that live here. So, if people want to talk about animal rights and animal liberation what do they say to the other animals, the native birds, whose homes the deer we shoot wreck? (Jake, deer hunter)

Hunters, such as Jake, have a keen appreciation for the broader environment in which they hunted and articulated that hunting was a necessary practice to ensure the overall stability of New Zealand's fragile and unique ecosystem. Certainly, much time was spent during hunts absorbing breathtaking vistas and listening to the "dawn chorus" birdsong. This forms the basis of the perspectives hunters privilege as well as the historical and sociological values hunters have inherited, and the biological, ecological, and environmental interactions in New Zealand. In essence, analyses of hunting cannot ignore the debate between conflicting animal interests often manifest through conflicts between environmental holism and the individualism of animal rights/animal liberation perspectives. That being said, little consensus is evident on what that ecosystem should be like and therefore the most appropriate form of ecosystem management. However, hunters view themselves as playing a role in ensuring, to some extent, that native flora and fauna are able to survive courtesy of keeping introduced (game) animal numbers low (Parkes \& Murphy, 2003) and see the 
value of hunting as protecting the ecosystem not just in the interest of the game animals and the hunter. As such, hunters argue that through hunting they build relationships through which they work to harvest nonendemic animals that benefits hunters, the land, and other animals therein. Similarly, Lovelock (2008) notes that in the backcountry of New Zealand hunters may actually hold a superior ethical argument when compared with other backcountry users who enjoy encounters with introduced species in native ecosystems. However, in terms of ecosystem management hunters routinely argued that while hunting was able to make some contribution to conservation efforts, recreational hunting alone would be insufficient, but if they were able to derive some pleasure through being in the backcountry and through eating meat they had procured themselves then this should entail some element of moral praiseworthiness. It would be unwise to equate this element of moral praiseworthiness as based on a purely consequentialist utilitarian perspective (cf. Singer, 1992). However, as should be evident by now, in the New Zealand context removal of introduced species by hunters works to the benefit of native animals and plants. The central point here is that the practice of hunting is not constructed in relation to abstract calculations of utility but through engaged relationship building with animals and the environment in situ. Hunters regularly speak of the need to protect the environment and native animals because they are intimately aware of the inherent value of, and the damage game causes to, them. A central part of hunting is identifying 'sign', which includes droppings, rootings, and/or damage caused by animals eating or rubbing trees. Outlining the relationships hunters establish with the backcountry is not to forward hunting as either a necessary or sufficient component of ecosystem protection and/or management. Instead it reinforces that reducing discussions and analyses of human and animal interactions in hunting to one of killing is neither congruent with the practice and value of hunting for hunters nor the impact hunting has on individual animals.

Broadly speaking, then, the relationship hunters establish with the landscape through successive trips into remote backcountry areas and engagement with often inhospitable environments and weather works to undermine any notion that engaging with animals through hunting is ethically indefensible as compared with engaging with animals in nonhunting practices. While the latter guarantees the life of an individual animal it undercuts the lives of other (individual) animals, plants, and topography of the environment in which these interactions take place. In effect, bracketing out broader environmental issues in hunting practices in New Zealand both ignores the complexity of human-animal relationships in hunting practices as well as questions of ethical responsibilities.

There is a real paradox here for conservation: on one hand you don't want to kill an animal but on the other you realise that the animals you don't kill are killing the native birds and destroying the environment. I really don't know what is "right" here, but I do know which side I am on (Andy, deer-stalker).

\section{Conclusions and Future Directions}


It is important to conclude this paper by restating that the arguments forwarded here are but a beginning point. The complexities of hunting anywhere, and hunting in New Zealand specifically, require much further empirical and theoretical attention from critically-minded scholars. In this paper I have argued that the practice of hunting cannot be understood on the basis of a priori ethical principles be they anti- or prohunting. One profitable avenue for future work, then, is attending to the relationships hunters build through the act of hunting. Obviously, such a perspective should not ignore the violence of hunting but neither should it reduce hunting to domination through violence. Those I hunted with and spoke to about hunting demonstrated that the practice of hunting is based on repeated engagement with a range of animals and the backcountry and as such the act of killing is but one, albeit inescapable and important, part of the story of hunting.

Importantly, and contra much of the literature critical of hunting, hunting in New Zealand for many is valued as an egalitarian practice that facilitates experiences in the proverbial great outdoors and not validation or confirmation of masculinity. In developing relationships with animals, hunters must engage with animals on the terms of the animal itself and not in predefined environments or roles. Thus, while animals may or may not comprehend sporting culture, they certainly understand hunting. Against this backdrop, then, contemporary hunting practices and hunters present a complex, nuanced, and at times contradictory orientation toward animals. Of particular import is that target species sit in a complex network simultaneously understood as valued things in nature, pests, and meat as shaped by the historical contingencies of target species as introduced, rather than indigenous, animals (Figgins \& Holland, 2012) broader ecological considerations (Parkes \& Murphy, 2003), and social mores related to identity formation for hunters (Daigle, Hrubes, \& Ajzen, 2002; Leopold, 1966; Ortega, 1972). Thus, those whom I hunted with and spoke to about hunting illustrated that hunting cannot be understood purely through the fact that animals die. Moreover, hunting, in New Zealand at least, is not conducted primarily for the purpose of or in a manner that works to reinforce masculine dominance over nature or overtly sexualized demonstrations of power (Bronner, 2008; Kalof, Fitzgerald, \& Baralt, 2004; Luke, 1995). Indeed, outside New Zealand, Mary Zeiss Stange has roundly critiqued such perspectives (1998, 2003). Instead, hunting in New Zealand has developed and is currently practiced in manner that is articulated through a situated knowledge of nature (Cronon, 1995) that recognizes the 'reciprocated complexities' (Haraway, 2008 p.42) of the relationships between hunters, game, the environment, and other animals. As such, hunters in the New Zealand context have developed an ethical perspective and imperative related to hunting that reflects a relational perspective.

In essence, the relationships are not simply hunter-hunted but variously function in roles as hunter, conservationist, provider, teacher, student, food, pest, commodity, and muse. Therefore, in line with the dominant critiques of hunting as related to carnism more broadly whereby the historical, cultural, and social contingencies account for the differentiation between edible and inedible, hunters have discerned those which are quarry and not in relation to the readily identifiable introduced species as well as the facilitation of particular 
experiences in the backcountry of New Zealand. Recreational hunters are keenly aware of the subjectivity of the animals and how the animals are indifferent to their legal classifications in a manner reminiscent of animal standpoint theory, however, little guidance is provided from such perspectives as to how violence can be conducted or indeed condoned despite positive impacts for other animals. This is not to condone any and all violence toward animals or indeed seek to justify, rationalize, or defend recreational hunting in New Zealand. Instead, it points to the difficulty in studying animals in human sporting and recreational practices in a manner that recognizes the value of all animals but without the blinkers of preexisting political and ethical convictions. Future work, then, needs to be predicated on understanding actions more broadly and being willing to be informed by other branches of knowledge that might sit uncomfortably with political convictions and personal ethics. In sum, what has been at stake in this paper is not the defensibility of hunting as a form of human- animal interaction but to demonstrate, through ethnographic engagement with hunters, the ethical perspectives hunters develop and how this guides the practice of hunting.

\section{References}

Adams, C.J. (1999). The sexual politics of meat: A feminist-vegetarian critical theory. (20th Anniversary Edition). New York, NY: Continuum.

Adams, C.J., \& Donovan, J. (Eds.). (1995). Animals and women: Feminist theoretical explorations. Durham, NC: Duke University Press.

Adler, P., \& Adler, P. (1985). Membership roles in field research. Newbury Park, CA: Sage.

Adler, P., \& Adler, P. (2000). Constructions of deviance: Social power, context, and interaction. Belmont, CA: Wadsworth.

Atkinson, M. (2010). Fell Running in Post-Sport Territories. Qualitative Research in Sport \& Exercise, 2(1), 109-132. doi:10.1080/19398441.2010.488020

Atkinson, M., \& Gibson, K. (2013). Communion without collision: Animals, sport and interspecies co-presence. In J. Gillett \& M. Gilbert (Eds.), Sport, animals and society( pp. 268-289). London: Routledge.

Atkinson, M., \& Young, K. (2008). Deviance and social control in sport. Champaign, IL: Human Kinetics.

Anderson, W. (1992). Climates of opinion: acclimatization in nineteenth-century France and England. Victorian Studies, 35, 135-157.

Banwell, D.B. (2001). The wapiti and the moose. Auckland: Halcyon Press.

Banwell, D.B. (2011). The red deer: Part II. Auckland: Halcyon Press.

Beauchamp, T.L., Orlans, B., Dresser, R., Morton, D.B., \& Gluck, J.P. (2008). The human use of animals: Case studies in ethical choice. Oxford: University of Oxford Press.

Best, S. (2013) Animal liberation and moral progress: The struggle for human evolution. Lanham, MA: Rowman \& Littlefield.

Bronner, S. (2008). Killing tradition: Inside hunting and animal rights controversies. Lexington, KY: University Press of Kentucky.

Bulliet, R.W. (2005). Hunters, herders, and hamburgers: The past and future of human-animal relationships. New York, NY: Columbia University Press.

Caughley, G. (1983). The deer wars. Auckland: Heinemann.

Challies, C.N. (1985). Establishment, control, and commercial exploitation of wild deer in New Zealand. Royal Society of New Zealand Bulletin, 22, 23-26. 
Cronon, W. (1995). The trouble with wilderness; or, getting back to the wrong nature. Environmental History, 1(1), 7-55. doi:10.2307/3985059

Crump, B. (1960). A good keen man. Wellington: A. H. \& A. W. Reed.

Crump, B. (1992). The life and times of a good keen man: The first of a trilogy. Opotiki: Barry Crump Associates.

Curry, N. (2004). The divergence and coalescence of public outdoor recreation values in England and New Zealand: An interplay between rights and markets. Leisure Studies, 23(3), 205-223 doi:10.1080/0261436042000251978

Daigle, J.J., Hrubes, D., \& Ajzen, I. (2002). A comparative study of beliefs, attitudes and values among hunters, wildlife viewers and other outdoor recreationists. Human Dimensions of Wildlife, 7, 1-19. doi:10.1080/108712002753574756

Davis, K. (2014). Afterword. In A.J. Nocella, J. Sorenson, K. Socha, \& A. Matsuoka (Eds.), Critical Animal Theory (pp. 221-228). New York, NY: Lang.

Dizard, J.E. (1999). Going wild: Hunting, animal rights, and the contested meaning of nature. London: Pimlico.

Elias, N., \& Dunning, E. (1986). Quest for excitement: Sport and leisure in the civilizing process. Oxford: Basil Blackwell.

Franklin, A.S. (2008). The "animal question" and the "consumption" of wildlife. In B. Lovelock (Ed.), Tourism and the consumption of wildlife: Hunting, shooting and sport fishing (pp. 31-44). London: Routledge.

Feldman, J.W. (2001). Treaty rights and pigeon poaching: Alienation of Maori access to Kereru, 1864-1960. Wellington: Waitangi Tribunal.

Figgins, G. (2008). Game estates and guided hunting: Two perspectives of red deer hunting. In B. Lovelock (Ed.), Tourism and the consumption of wildlife: Hunting, shooting and sport fishing (pp. 88-98). London: Routledge.

Figgins, G., \& Holland, P. (2012). Red deer in New Zealand: Game animal, economic resource, or environmental pest? New Zealand Geographer, 68(1), 36-48. doi:10.1111/ j.1745-7939.2012.01219.x

Garner, R. (2005). Animal ethics. Cambridge: Polity Press.

Gold, R. (1958). Roles in sociological field observation. Social Forces, 36(3), 217223. doi: $10.2307 / 2573808$

Haraway, D. (2008). When Species Meet. Minneapolis, MN: University of Minnesota Press.

Harris, L.H. (2002). The deer menace: A history of government pest control operations 1930 - 1987. Wellington: L.H. Harris.

Held, V. (2006). The Ethics of Care. New York, NY: Oxford University Press.

Herzog, H. (2010). Some we love, some we hate, some we eat: Why it's so hard to think straight about animals. New York, NY: Harper.

Holloway, J.S. (1991). Role of commercial harvesting in the management of wild deer. New Zealand Journal of Forestry, 36(1), 3-4.

Hunter, K. (2008). Hunting: A New Zealand history. Auckland: Random House.

Laufer, P. (2012). No animals were harmed: The controversial line between entertainment and abuse. Guilford. CT: Lyons Press.

Lovelock, B. (2008). An introduction to consumptive wildlife tourism. In B. Lovelock (Ed.), Tourism and the consumption of wildlife: Hunting, shooting and sport fishing (pp. 3-30). London: Routledge. 
Kalof, L., Fitzgerald, A., \& Baralt, L. (2004). Animals, women, and weapons: Blurred sexual boundaries in the discourse of sport hunting. Society \& Animals, 12(3), 237-251. doi:10.1163/1568530042880695

Kellert, S.R. (1978). Attitudes and characteristics of hunters and anti-hunters. Transactions Forty-Third North American Wildlife Conference, 43: 41223.

Kheel, M. (2008). Nature ethics: An ecofeminist perspective. Lanham, MD: Rowman \& Littlefield.

Leopold, A. (1966). A sand county almanac. Ballantine. NY: New York Sierra Club. Leopold, A. (1991a). The conservation ethic. In S. Flader \& J.B. Callicott (Eds.), The river of the mother of God and other essays by Aldo Leopold (pp. 181-192). Madison, WI: University of Wisconsin Press.

Leopold, A. (1991b). The ecological conscience. In S. Flader \& J.B. Callicott (Eds.), The river of the mother of God and other essays by Aldo Leopold (pp. 338-346). Madison, WI: University of Wisconsin Press.

Luke, B. (1995). Taming ourselves or going feral? Toward a nonpatriarchal metaethic of animal liberation. In C.J. Adams \& J. Donovan (Eds.), Animals and women: Feminist theoretical explorations (pp. 290-319). Durham, NC: Duke University Press.

Marvin, G. (2005). Sensing nature: Encountering the world in hunting. Ethnofoor, 18(1), 15-26.

Marvin, G. (2010). Challenging animals: Project and process in hunting. In S. Pilgrim \& J. Pretty (Eds.), Nature and Culture: Rebuilding Lost Connections (pp. 145-164). London: EarthScan.

Marvin G. (2011). Working within: An ethnographer in human-animal worlds, in M. DeMello (Ed.) Animals and Society: An Introduction to Human-Animal Studies (pp.123-125). New York, NY: Columbia University Press.

McLeod, C.M. (2007). Dreadful/delightful killing: The contested nature of duck hunting. Society and Animals 15, 151-167

Miller, C.A., \& Vaske, J.J. (2003). Individual and situational influences on declining hunter effort in Illinois. Human Dimensions of Wildlife, 8, 263-276. doi:10.1080/716100421

Ortega y Gasset, J. (1972). Meditations on hunting. New York, NY: Charles Scriner's Sons.

Parkes, J., \& Murphy, E. (2003). Management of introduced mammals in New Zealand. New Zealand Journal of Zoology, 30, 335-359. doi:10.1080/03014223.2003.9518346

Parkes, J.P., Nugent, G., \& Warburton, B. (1996). Commercial exploitation as a pest control tool for introduced mammals in New Zealand. Wildlife Biology, 2, 171-177.

Peterson, A. (2013). Being animal: Beasts and boundaries in nature ethics. New York, NY: Columbia University Press.

Radder, L. (2005). Motives of international trophy hunters. Annals of Tourism Research, 32(4), 1141-1144. doi:10.1016/j.annals.2004.12.003

Rolston, H. (1988). Environmental ethics: Duties to and values in the natural world. Philadelphia, PA: Temple University Press.

Scrutton, (2000). Animal rights and human wrongs. London: Metro.

Simberloff, D. (2003). Confronting introduced species: a form of xenophobia? Biological Invasions, 5(1), 179-192. doi:10.1023/A:1026164419010 
Simberloff, D. (2005). Non-native species do threaten the natural environment! Journal of Agricultural \& Environmental Ethics, 18(4), 595-607. doi:10.1007/s10806-005-2851-0

Singer, P. (1992). Animal liberation. London: Pimlico

Stange, M.Z. (1998). Women the hunter. Boston, MA: Beacon Press.

Stange, M.Z. (Ed.). (2003). Heart shots: Women write about hunting. Mechanicsburg, PA: Stackpole Books.

Stokvis, R. (1992). Sports and civilization: Is violence the central problem? In E. Dunning \& C. Rojek (Eds.), Sport and leisure in the civilizing process: Critique and counter-critique (pp. 121-136). Toronto: University of Toronto Press.

Slote, M. (2007). The ethics of care and empathy. London: Routledge.

Swan, J. (1995). In defense of hunting: Yesterday and today. New York, NY: Harper.

Tester, K. (1992). Animals and Society: The humanity of animal rights. London: Routledge.

Tyrrell, M. (2010). Biodiversity and cultural diversity: The interdependent and the Indistinguishable. In S. Pilgrim \& J. Pretty (Eds.), Nature and Culture: Rebuilding Lost Connections (pp. 123-144). London: EarthScan.

Varner, G. (1998). In nature's interests? Animal rights and environmental ethics. New York, NY: Oxford University Press.

Weitzenfeld, A., \& Joy, M. (2014). An overview of anthropocentrism, humanism, and Speciesism. In A.J. Nocella, J. Sorenson, K. Socha, \& A. Matsuoka (Eds.), Critical Animal Theory (pp. 3-27). New York, NY: Lang.

Willems, H. (2009). The deer cullers. Auckland: Halcyon Press.

Woods, A. \& Kerr, G.N. (2010). Recreational hunting game hunting: Motivations, satisfaction and participation. Land environment and people research report, 18.

Yerex, D. (2001). Deer: The New Zealand story. Christchurch: Canterbury University Press. 